RESEARCH PAPER

\title{
The tobacco industry's use of Wall Street analysts in shaping policy
}

\author{
B C Alamar, S A Glantz
}

See end of article for

authors' affiliations

Tobacco Control 2004;13:223-227. doi: 10.1136/tc.2003.006643

Correspondence to:

Professor Stanton A Glantz,

Center for Tobacco

Control, Research \&

Education, University of

California, San Francisco,

530 Parnassus Ave, Suite

366, San Francisco, CA

94143, USA; glantz@

medicine.ucsf.edu

Received

8 November 2003

Accepted 13 April 2004

Objective: To document how the tobacco industry has used Wall Street analysts to further its public policy objectives.

Methods: Searching tobacco documents available on the internet, newspaper articles, and transcripts of public hearings.

Results: The tobacco industry used nominally independent Wall Street analysts as third parties to support the tobacco industry's legislative agenda at both national and state levels in the USA. The tobacco industry has, for example, edited the testimony of at least one analyst before he testified to the US Senate Judiciary Committee, while representing himself as independent of the industry.

Conclusion: The tobacco industry has used undisclosed collaboration with Wall Street analysts, as they have used undisclosed relationships with research scientists and academics, to advance the interests of the tobacco industry in public policy.

$\mathrm{T}$ he tobacco industry has a well documented history of using research scientists and academics to advance the interests of the tobacco industry in both policy and public opinion. ${ }^{1-4}$ The tobacco industry has paid research scientists and academics to present research designed to question the evidence that secondhand smoke causes disease. ${ }^{12}$ This article demonstrates that this strategy of using seemingly independent third parties was extended to the financial analysts that work for the large investment banks on Wall Street to support the industry's political and public policy agenda. The tobacco industry has used the financial analysts to lobby members of Congress, present tobacco industry friendly testimony to a Congressional committee, and give a tobacco industry friendly presentation to a Florida committee discussing potential policies towards the tobacco industry. The tobacco industry has collaborated with analysts from the investment banking industry to present the tobacco industry point of view for lawmakers from an "independent" source.

The investment banking industry is riddled with conflicts of interest. ${ }^{5}$ Analysts that are employed by investment banks are paid, either directly or indirectly, through the revenues of the investment bank. Positive ratings on stocks, be they initial public offerings for new firms or established companies, help attract new business for the investment bank. The new business will increase the investment banking revenue, thus analysts have an incentive to bias their recommendations upwards to attract business from the companies they cover. This conflict of interest and the resulting biased and misleading investment research that financial analysts who work for these banks provided led the US Securities and Exchange Commission (SEC) and New York State Attorney General Eliot Spitzer to file fraud and other civil claims against 10 of Wall Street's largest firms in federal court on 30 September 2002. The settlement of the civil claims in April 2003 resulted in payments from the 10 firms of $\$ 1.4$ billion to the SEC and individual investors. ${ }^{5}$ The settlement also established new regulations that attempt to separate the analysts from the investment bankers by limiting when and how they may communicate. The settlement also requires that the firms provide investors with at least three different sources of independent research. ${ }^{5}$
While the financial community is the most significant part of the financial analysts' world, it is not their only realm of influence. Analysts are regularly called upon by state and federal governments to give testimony on the predicted effects of proposed legislation on the industries they follow. Wall Street analysts have testified, for example, on media ownership rules, ${ }^{6}$ US tax policy and US owned foreign operations, ${ }^{7}$ and the international competitiveness of US companies. ${ }^{8}$ While the analysts are a natural source of information and opinion on these industries, the conflicts of interest that exist need to be clearly recognised in the policy making process. Policymakers are not made aware of the closeness of the relationships between the analysts and the companies that they cover.

In particular, for the two analysts discussed in detail below, their conflicts of interest, in regards to their firms' revenues attributable to investment banking relationships with tobacco companies, and their collaboration with the firms, are never noted in their role as policy advisers. The first analyst, David Adelman, worked for Morgan Stanley which, at the time of the activities described below, owned approximately $\$ 1.7$ billion of Philip Morris stock $^{9}$ and functioned as an underwriter on Philip Morris bond offerings. ${ }^{10}$ The second analyst, Martin Feldman, worked for Smith Barney, a subsidiary of Citigroup, which owned approximately $\$ 894$ million of Philip Morris stock ${ }^{11}$ and also functioned as the underwriter on several Philip Morris bond offerings. ${ }^{10}$ We document how Philip Morris-USA (PMUSA) used these analysts, who represented themselves as independent, to advance the interest of the tobacco industry in public policy debates.

\section{METHODS}

We began by searching the Legacy Tobacco Documents Library (www.legacy.library.ucsf.edu) and www.tobaccodocuments.org for the names of the lead Wall Street tobacco analysts as of 1998 (David Adelman, Martin Feldman, Roy

Abbreviations: FDA, Food and Drug Administration; MSA, Master Settlement Agreement; PMUSA, Philip Morris USA; SEC, US Securities and Exchange Commission 
Burry, Gary Black, and Marc Cohen) using complete names, last names and first initial, and just last names. We also searched for the names of the largest investment banks (Morgan Stanley, Merrill Lynch, Goldman Sachs, JP Morgan, Lehman Brothers and Bear Stearns). Review of these documents indicated specific people at PMUSA that had contact with the analysts (John Hoel, director of federal tobacco issues, Washington relations office, Philip Morris Management Corporation; Marc Berlind, senior assistant general counsel, worldwide regulatory affairs, Philip Morris Management Corporation; and Steve Parrish, senior vice president of corporate affairs, Philip Morris Inc). Having identified the key contacts, we searched for and identified emails and memos authored by these individuals that related to the financial analysts. We then searched the adjacent Bates numbers of these documents as well as the complete file locations in which these documents were located. We identified relevant documents relating to David Adelman and Martin Feldman. No documentation regarding contact between the other analysts (Roy Burry, Gary Black, and Marc Cohen) and the legislative teams of any of the tobacco companies was found. All searches were conducted between March 2003 and April 2004.

\section{RESULTS}

The documents that detail the connections between the analysts and the tobacco industry surround two events. The first is the debate in Congress regarding the McCain Bill, national legislation that sought to implement the terms of the "Global Settlement" between state attorneys general, private lawyers, some public health interests, and the tobacco industry; the second is a debate in Florida regarding Florida's policy toward the tobacco industry. In the debate regarding the McCain Bill, two analysts were used to lobby members of Congress and give testimony to a Congressional committee. In Florida, one of the analysts was asked, by a state committee exploring various policy options in regards to lawsuits against the tobacco industry as well as the Florida settlement with the tobacco industry. PMUSA had a close working relationship with this analyst and his testimony to the committee was very favourable towards the tobacco industry. The documents discussed below show that PMUSA worked with analysts to present information favourable to the tobacco industry to policymakers.

\section{The McCain bill}

On 20 June 1997 the tobacco industry and a group of state attorneys general and private lawyers announced the "Global Settlement" of broad private class action and state Medicaid cost recovery lawsuits that had been filed against the tobacco industry. ${ }^{12}$ Part of the agreement provided the industry with immunity from most types of future lawsuits in exchange for the tobacco industry dropping opposition to limited Food and Drug Administration (FDA) regulation of tobacco products, acceptance of some restrictions on its advertising practices, creation of a fund to reimburse people injured by tobacco, and annual payments to the state governments. Because of the immunity and FDA provisions, the "Global Settlement" was not a settlement in the strict legal sense, but rather a proposal for implementing federal tobacco legislation. Arizona Senator John McCain (R), the chairman of the Senate Commerce Committee, sponsored the resulting legislation (Senate Bill 1415) that would have enacted the necessary provisions of the settlement. The tradeoff between granting the tobacco companies legal immunity in exchange for the concessions the industry made was very controversial within the public health community, ${ }^{13}$ with some viewing it as a sensible compromise ${ }^{14}$ and others considering it a mistake. $^{12}$
While the McCain Bill as introduced essentially implemented the original compromise embodied in the Global Settlement, by the time the bill passed the Commerce Committee on 1 April $1998,{ }^{15}$ it had been significantly altered to strengthen the public health provisions and reduce the protections that it provided the tobacco industry. The amended bill contained stronger FDA regulatory powers, stronger limitations on tobacco marketing to children, and increased the total cost to the tobacco industry to an estimated $\$ 516$ billion from the $\$ 368.5$ billion in the original settlement. ${ }^{16}$ The increased costs were in the form of a $\$ 1.10$ increase in the federal excise tax on cigarettes, and a provision which would impose fines on the industry if youth smoking did not drop to certain levels. ${ }^{16}$ Most important, limitations on class action suits and punitive damages that had granted the industry de facto legal immunity were removed. ${ }^{16}$

Without the immunity provisions, the tobacco industry no longer had any interest in seeing the McCain Bill become law and began to fight its passage. The tobacco industry launched a $\$ 40$ million advertising campaign aimed at defeating the bill. ${ }^{16}$ The campaign attempted to frame the bill as the "largest tax increase in history"17 and a bureaucratic mess. ${ }^{17}$

On 30 April 1998, the bill moved to the Senate Judiciary Committee, chaired by Utah Senator Orin Hatch (R-Utah). The issue in the McCain bill for the Judiciary Committee was cigarette smuggling. One of the industry's documented strategies to fight legislation (primarily tax increases) is to raise the spectre of smuggling to both policymakers and the public. ${ }^{18}$ Cigarette smuggling, as it related specifically to the McCain Bill, was first raised by tobacco lobbyist $\mathrm{J}$ Phil Carlton on 2 April 1998 when he predicted that the tax increase in the bill could revitalise the black market for cigarettes. ${ }^{19}$ The tobacco industry further pushed the issue in an advertising campaign which claimed that "Washington is creating a serious new law enforcement problem" ${ }^{17}$ Senator Hatch also picked up the theme of smuggling before the Judiciary Committee hearing. He predicted that Wall Street analysts would testify that the McCain bill would drive cigarette prices to over $\$ 5$ per pack which would create a black market for cigarettes. ${ }^{20}$

The McCain Bill was eventually filibustered on the Senate floor on 17 June 1998 and died. ${ }^{16}$ The Master Settlement Agreement (MSA), a narrowed version of the original settlement, was then signed in November 1988. The MSA settled the state lawsuits in exchange for annual payments from the tobacco industry and numerous restrictions on the advertising of cigarettes. ${ }^{13} 21$ The MSA was not the comprehensive piece of tobacco control legislation that the McCain bill was supposed to have been, but rather a traditional legal settlement between 46 state attorneys general and the tobacco industry that did not require implementing legislation to enact.

\section{Wall Street analysts on Capitol Hill}

The PMUSA internal federal legislative lobbying group wrote weekly reports that described their activities titled "Weekly Bullet Report for Federal Tobacco Team". A key member of this group was John Hoel, Philip Morris' director of federal tobacco issues. In the 20 March 1998 report, 10 days before the Senate Commerce Committee was to vote on the McCain bill, Hoel describes that he "Arranged for Martin Feldman [of Smith-Barney] and David Adelman [of Morgan Stanley] to brief Majority and Minority staff of Senate Commerce Committee [and that he] Briefed Martin and David before meeting". ${ }^{22}$ Hoel continued to maintain daily contact with Adelman and Feldman through the week leading up to the Commerce Committee vote. ${ }^{23}$ 
On 30 April 1998 the Senate Judiciary Committee held its first hearing on cigarette smuggling titled "Tobacco Control Legislation and the Black Market." ${ }^{24}$ The committee heard testimony that attempted to establish a "trigger" price for mass cigarette smuggling of $\$ 4$ to $\$ 5$ a pack and two alternative projections for the price of cigarettes over the proceeding five years. ${ }^{24}$ The Clinton Administration, which supported the bill, ${ }^{19}$ was represented by Deputy Treasury Secretary Lawrence Summers. Secretary Summers presented an economic model projecting the price of cigarettes for the following five years to be below this level. ${ }^{24}$ Summers' testimony undercut the tobacco industry's argument of widespread smuggling, because, by his projections, the price of cigarettes would not rise to the level that would supposedly create a rampant black market.

After Secretary Summers' testimony, Morgan-Stanley's David Adelman, who was invited by the committee, testified that the assumptions that Summers used in his projections were not valid. He then presented his own projections that predicted that the price of cigarettes would rise to between $\$ 4.53$ and $\$ 5.66$ a pack over the next five years, and that these prices would spur huge levels of smuggling and violence related to the smuggling. ${ }^{24}$

Adelman opened his testimony by saying: "To put my comments into perspective, I'm a tobacco industry analyst at Morgan Stanley Dean Witter, and my job is to provide objective investment advice to the firm's clients [emphasis added]. ${ }^{24} \mathrm{He}$ did not mention his regular communications with Philip Morris' Hoel. ${ }^{24}$ Adelman made no mention of the fact, documented in Philip Morris' Weekly Bullet Report for Federal Tobacco Team dated 4 May 1998, the week that overlaps the Judiciary Committee hearing, that PMUSA's Hoel "Prepared David Adelman to testify before Senate Judiciary, including editing written testimony" ${ }^{25}$

The assumptions that Adelman describes in his testimony were made in such a way as to maximise the estimated effect of the McCain Bill on cigarette prices. Adelman's projections included the maximum possible fine that could be levied on the tobacco industry for failing to reduce youth smoking, an acceleration in the rate of increase in the wholesale price of cigarettes, an increase of state level excise taxes on cigarettes of $7 \%$ per year, and an increase in the mark up at the retail level. ${ }^{24}$ These increases were larger than had been observed historically. Adelman did not justify the assumption that the tobacco industry would continue marketing to teens in a way that would lead to the maximum fine for failure to reduce teen smoking, nor did he present data to back up his estimated price increases at the wholesale level, the estimated annual increase in state level excise taxes, or the assumed increase in the retail margin. ${ }^{24}$ His assumptions, and thus his projected price, do not appear "reasonable"24 as he claims, but rather designed to artificially increase the projected price of cigarettes.

The high estimated price resulting from these unrealistic assumptions supported the industry claims that the McCain Bill would lead to a very high price of cigarettes and increased smuggling. Senator Hatch, chairman of the Judiciary Committee, accepted this argument and said: "my bottom line concern is that a rampant black market will increase crime, violence and will virtually assure that our teens will have ready access to cheap unregulated, potentially more harmful cigarettes." 24

While no changes were made to the bill in the Judiciary Committee, the hearing enabled the tobacco industry to push the issue of smuggling as a negative effect of the McCain Bill with the public. Numerous news articles ${ }^{26-28}$ and an opinion editorial in the Washington Post by the chairman and CEO of Brown \& Williamson Tobacco Corp, Nick Brookes, ${ }^{29}$ published after the hearing focused on predictions of the large black market in cigarettes that the bill would create. Philip Morris CEO Geoffrey C Bible invoked smuggling as one his main concerns in urging shareholders to tell their senators to vote against the bill. ${ }^{30}$ As they had done in the past, ${ }^{18}$ the tobacco industry successfully used claims of cigarette smuggling to help defeat legislation that they opposed.

The relationship between Hoel and the analysts did not end with the filibuster of the McCain Bill. According to the PM Weekly Bullet Report for Federal Tobacco Team, the relationship continued through at least February 1999. ${ }^{31-35}$ Hoel and Adelman were in regular contact discussing black markets, amendments to various legislation, the Federal Medicare suit, a suit filed in 1999 to recover federal Medicare costs related to tobacco use, and even Senate procedures. ${ }^{31-35}$

\section{Tobacco in Florida}

The use of "independent" analysts without disclosing their relationship to the tobacco industry to influence policy and public debate by PMUSA has not been limited to supporting its position on federal legislation. This strategy was also used for state level legislation in Florida. In April 2000, a Miami jury awarded the plaintiffs in a class action lawsuit brought against the tobacco industry on behalf of all Florida residents and citizens who had suffered adverse, tobacco related health problems (the Engle case) \$12.7 million in compensatory damages for three of the up to 500000 plaintiffs and \$145 billion in punitive damages for the entire class. ${ }^{36}{ }^{37}$ In order to appeal the judgment, under Florida law, the tobacco industry would be required to post a bond equal to the punitive damages plus 20\%; in this case the bond would be $\$ 162$ billion. $^{38}$

The tobacco industry insisted that a bond of this magnitude would force them to file for bankruptcy protection. $^{36}$ The state of Florida was due to receive $\$ 17.4$ billion over 25 years in payments from the tobacco industry as a result of a legal settlement with the tobacco industry similar to the MSA. A tobacco industry bankruptcy could greatly reduce or eliminate these payments. This threat from the tobacco industry caused concern for lawmakers who were planning on spending the payments they expected to receive. ${ }^{36}$

The Florida legislature acted to protect the tobacco industry in May 2000, motivated by a stated desire to protect the settlement payments. ${ }^{38}$ The legislature passed two laws that were both signed in to law by Governor Jeb Bush (R). The first was a cap on the appeal bond that the tobacco industry would have to post, limiting the appeal bond to $\$ 100$ million per company. ${ }^{38}$ The cap on the appeal bond quelled fears of any imminent bankruptcy. ${ }^{38}$ The second law established the Tobacco Settlement Financing Corporation and the Task Force on Tobacco Settlement Revenue Protection. ${ }^{39}$ The Tobacco Settlement Financing Corporation was established in order to, with further approval of the legislature, sell the income stream created by the Florida settlement with the tobacco industry as bonds to provide Florida with a certain current lump sum payment, instead of future annual payments from the tobacco industry that were dependent on cigarette sales and the financial health of the industry. As a result, the bonds would transfer the risk of not receiving the payments, due for instance to a tobacco industry bankruptcy, from the Florida taxpayers to bond investors. Once the risk of receiving the payments was transferred, the state would no longer have an interest in the financial health of the tobacco industry. The Task Force on Tobacco Settlement Revenue Protection, which was to comprise the Governor, Comptroller, Insurance Commissioner and three members each of the Florida House and Senate, was established to investigate whether the bonds should be sold or insurance on 
the payments from the tobacco industry should be purchased. ${ }^{39}$

In 2001, Adelman was asked to give a presentation to the Task Force, presumably as an independent third party; he had made no disclosure regarding his relationship with the tobacco industry. ${ }^{24}{ }^{40}$ Michael Kenny, Philip Morris vice president of investor relations, notes in an email to Hoel that Adelman was asked to comment on "Engle, the risks facing the tobacco industry, industry performance" ${ }^{\prime 4}$. It is unknown as to how PMUSA learned of the planned meeting of the Task Force. PMUSA did, however, closely monitor the situation. ${ }^{41}$

Adelman introduced himself to the Task Force committee by saying: "I'm not an advocate or a critic of [the tobacco industry]. But what I do for a living is do my best to inform institutional investors about the business prospects and legal risk profile of the industry. And, you know, as a result of that, I need to be accurate. ${ }^{\prime 40}$ He made no mention of his private discussions and briefings by Philip Morris lobbyists during and after the McCain Bill process.

Adelman's discussion portrayed the financial health of the industry in such a positive manner that it prompted Florida Senator Locke Burt (R-Ormond Beach) to question why Adelman's perception of the financial health of the industry was so positive.

Senator Burt: The picture you paint of the industry is, I think, a lot more positive than we heard in front of my committee last March or April. And I was just curious what has happened to the stock price of the big tobacco companies between last March and today.

Mr Adelman: ...You know, they've probably gone up about 80 percent over the last you know 12 to 18 months. $^{40}$

This statement on the stock price performance illustrates the upwardly biased nature of Adelman's perspective on the tobacco industry. The actual average performance of the three largest cigarette manufacturers in the USA (Philip Morris, RJ Reynolds, and British American Tobacco) was a $61 \%$ increase over the 12 months before the meeting and a $49 \%$ increase over the 18 months before the meeting, ${ }^{42}$ not the $80 \%$ he suggested in his answer to Senator Burt. Even though Adelman followed the stock price of the tobacco companies on a daily basis as a Wall Street analyst, he overstated the price performance of the tobacco stocks by $20-30 \%$.

After the presentation by Adelman, the Florida Task Force on Tobacco Settlement Revenue Protection issued its final report. The report included several recommendations including not selling bonds and not purchasing insurance for the payments that Florida was due under their settlement with the tobacco industry. ${ }^{43}$ These recommendations were beneficial to the tobacco industry because they ensured that the state of Florida maintains an ongoing interest in the financial health of the tobacco industry.

Executives at PMUSA were pleased with Adelman's presentation. In response to a question about the presentation from Nicholas Rolli, Philip Morris vice president investor relations and financial communications, Hoel replied that "Keith Teel [Attorney at Covington \& Burling, a law firm that works for tobacco companies] said he [Adelman] did well. I'll call David [Adelman] and ask him first hand." ${ }^{44}$

Since Adelman's presentations and testimony were consistently helpful to the tobacco industry, PMUSA looked for new ways to incorporate his assistance in other forums. Sean Murray, manager of corporate communications at Philip Morris Inc, sent an email to Hoel asking for his opinion of

\section{What this paper adds}

The tobacco industry has a well documented history of using research scientists and academics to advance the interests of the tobacco industry in both policy and public opinion. The tobacco industry has paid research scientists and academics to present research designed to question the evidence that secondhand smoke causes disease. No research has been previously done, however, on the use of Wall Street analysts, by the tobacco industry, to shape both policy and public opinion.

This paper documents the connection between Wall Street analysts and the tobacco industry. The tobacco industry has used the financial analysts to lobby members of Congress, present tobacco industry friendly testimony to a Congressional committee, and give a tobacco industry friendly presentation to a Florida committee discussing potential policies towards the tobacco industry. The tobacco industry has collaborated with analysts from the investment banking industry to present the tobacco industry point of view for lawmakers from an "independent" source.

Adelman, for potential participation in an internal conference call. Hoel responded via email on March 20, 2001:

I think he [Adelman] is a great guy who is very smart. After working with him during the McCain bill, we became personal friends. Let me know how I can help and what you[r] ideas are for using him in San Antonio. ${ }^{45}$

\section{DISCUSSION}

There are well documented examples of how the tobacco industry has used research scientists and academics to help shape both public opinion and public policy ${ }^{1-4}$ This paper provides the first documented inclusion of purportedly independent financial analysts in this strategy. Two Wall Street analysts had close contact with the PMUSA legislative team. The Philip Morris "Weekly Bullet Report for the Federal Tobacco Team"22 $232531-35$ and PMUSA internal emails $^{4144}$ document the close relationship between Wall Street analysts (Adelman and Feldman) with Hoel, a member of the federal lobbying team of a company they cover. The analysts never publicly disclosed this close relationship to any of the public policy making bodies where they testified. Quite the contrary, they made a point of representing themselves as independent. ${ }^{24} 40$ The analysts claimed independence, yet Adelman, for example, allowed his testimony to be edited by a company that had a material interest in the pending legislation about which he was testifying. ${ }^{25}$

The relationship between the financial analysts and PMUSA's Hoel is also further evidence of the widespread conflicts of interest that exist between the investment analysis business and the investment banking revenues that pay the analysts' salaries and bonuses. Until all of these activities, not just those in the financial world, are dealt with transparently, investors and policymakers cannot have confidence that they are receiving unbiased reports. Policymakers, working on tobacco or other legislation, also need to be aware that the opinions that they receive from Wall Street analysts may not be the independent and unbiased reports that they are represented to be. Full disclosure of both the financial interests of the analysts as well as the contact that they have with the companies that they are researching should be demanded by policymakers. Without this type of disclosure, policymakers will not know 
the full context of the information and opinions that they receive from the analysts.

\section{ACKNOWLEDGEMENTS}

This work was supported by National Cancer Institute Grant CA61021.

\section{Authors' affiliations}

B C Alamar, S A Glantz, Center for Tobacco Control, Research \& Education, University of California, San Francisco, San Francisco, California, USA

\section{REFERENCES}

1 Barnoya J, Glantz S. Tobacco industry success in preventing regulation of secondhand smoke in Latin America: the "Latin Project". Tobacco Control 2002; 11:305-14.

2 Ong E, Glantz S. Constructing "sound science" and "good epidemiology": tobacco, lawyers, and public relations firms. Am J Public Health 2001;91:1749-57.

3 Muggli M, Forster J, Hurt R, et al. The smoke you don't see: uncovering tobacco industry scientific strategies aimed against environmental tobacco smoke policies. Am J Public Health 2001:91:1419-23.

4 Muggli M, Hurt R, Blanke D. Science for hire: a tobacco industry strategy to influence public opinion on secondhand smoke. Nicotine Tob Res 2003;5:303-14

5 White B, Day K. SEC Approves wall street settlement: conflicts of interest targeted. Washington Post. 29 April 2003:Sect. A1.

6 US Senate Committee on Commerce Science \& Transportation. Media ownership. Website: US Senate Committee on Commerce Science \& Transportation, 2003. http://commerce.senate.gov/hearings/ witnesslist.cfm?id =950. [Accessed November 5 2003]

7 US Senate Committee on Finance. Examination of US tax policy and its effect on the domestic and international competitiveness of US owned foreign operations. Website: US Senate Committee on Finance; 2003. http:// finance.senate.gov/sitepages/hearing071503.htm. [Accessed November 5 2003]

8 US Senate Committee on Finance. The Role of the Extraterritorial Income Exclusion Act in the international competitiveness of US Companies. Website: US Senate Committee on Finance; 2002. Accessed: November 5, 2003. $\mathrm{http}: / /$ finance.senate.gov/sitepages/2002HearingF.htm/ hearing073002.htm. [Accessed November 5 2003]

9 Morgan Stanley - Dean Witter. Securities and Exchange Commission Form 13F-E; 1998 June. www.sec.gov. [Accessed March 2004]

10 Philip Morris Companies Inc. Securities and Exchange Commission Form 424B2; 1997-1999. www.sec.gov. [Accessed March 2004]

11 Citigroup. Securities and Exchange Commission Form 13F-E; 1999 June. www.sec.gov. [Accessed March 2004]

12 Fox B, Lightwood J, Glantz S. A public health analysis of the proposed resolution of [the 1997 United States] Tobacco Litigation. Center for Tobacco Control Research and Education San Francisco: 1998 February 1. http:// repositories.cdlib.org/ctcre/tcpmus/US1998/

13 Givel M, Glantz S. The "global settlement" with the tobacco industry: 6 years later. Am J Public Health 2004;94:218-24.

14 Pertschuk M. Smoke in their eyes: lessons in movement leadership from the tobacco wars. Vanderbilt University Press, 2001.

15 Kellman L. Senate Approves Tobacco Bill. Associated Press 1 April 1998. http://www.forces.org/articles/files/senate.htm.

16 Anon. Facts on file. Senate kills Tobacco Bill. World News Digest 1998. http://www.facts.com/wnd/tobc.htm.

17 Kurtz H. The Democrat who switched and fought; former Gore confidant formulated tobacco industry's effective ad blitz. Washington Post 19 June 1998: Sect A1.

18 Alamar B, Mahmoud L, Glantz S. Cigarette smuggling in California: fact and fiction. Center for Tobacco Control Research and Education San Francisco: 2003 July. http://repositories.collib.org/ctcre/tcpmus/Smuggling2003/.

19 Connolly C, Torry S. Tobacco Bill Clears Senate Panel; \$516 Billion Measure Hikes Fees, Restricts Ads, Limits Liability. Washington Post, 2 April 1998:Sect. Al.

20 Price JH. Hatch aims to soften McCain Tobacco Bill; says high prices would bankrupt industry. Washington Times, 27 April 1998:Sect. A4..

21 National Association of Attorneys General. Multistate Settlement with the Tobacco Industry: National Association of Attorneys General; 1998. http://
www.tobacco.neu.edu/Extra/multistate_settlement.htm. [Accessed: March 2004]

22 Nicoli D. Weekly Bullet Report For Federal Tobacco Team. Philip Morris Companies Inc; March 20, 1998. Legacy Tobacco Documents Library. Bates No. 2078294648-2078294652.FEDA/PRODUCED. http:// legacy.library.ucsf.edu/tid//hq75c00. [Accessed May 29, 2003]

23 Nicoli D. Weekly Bullet Report For Federal Tobacco Team. Philip Morris Companies Inc; March 27, 1998. Legacy Tobacco Documents Library. Bates No. 2078294653-2078294659.FEDA/PRODUCED. http:// legacy.library.ucsf.edu/tid/mhq75c00. [Accessed May 29, 2003]

24 Federal News Service. Senate Judiciary Committee Hearing Re: Tobacco Control Legislation and the Black Market. Philip Morris Companies Inc; April 30, 1998. Legacy Tobacco Document Library. Bates No. 20741424192077162640.FEDA/PRODUCED. http://legacy.library.ucsf.edu/tid/ ghc52c00. [Accessed May 29, 2003]

25 Nicoli D. Weekly Bullet Report For Federal Tobacco Team. Philip Morris Companies Inc; May 4, 1998. Legacy Tobacco Documents Library. : , Access Date: May 29, 2003. Bates No. 2078294675-2078294680.FEDA/ PRODUCED. http://legacy.library.ucsf.edu/tid/qhq75c00.

26 Goldreich S. Cigarette taxes spawn black market. Washington Post, 22 May 1998: Sect. A1

27 Goldreich S. Chinese black market cigarettes find way into Washington State. Washington Times 2 May 1998.

28 Schwartz J. GOP Panel Disputes Tobacco Bill's Price. Washington Post, 11 May 1998:Sect. A4

29 Brookes N. Black Market Bonanza. Washington Post, 20 May 1998:Sect. A25

30 Berselli B. Tobacco CEO Assails Legislation. Washington Post, 1998:Sect. F3.

31 Nicoli D. Weekly Bullet Report For Federal Tobacco Team. Philip Morris Companies Inc; May 14, 1998. Legacy Tobacco Document Library. Bates No. 2078294681-2078294686.FEDA/PRODUCED. http:// legacy.library.ucsf.edu/tid/rhq75c00. [Accessed May 29 2003]

32 Nicoli D. Weekly Bullet Report For Federal Tobacco Team. Philip Morris Companies Inc; June 6, 1998. Legacy Tobacco Document Library. Bates No. 2078294694-2078294699.FEDA/PRODUCED. http:// legacy.library.ucsf.edu/tid/uhq75c00. [Accessed May 29, 2003]

33 Nicoli D. Weekly Bullet Report For Federal Tobacco Team. Philip Morris Companies Inc; June 12, 1998. Legacy Tobacco Document Library. Bates No. 2078294700-2078294704.FEDA/PRODUCED. http:// legacy.library.ucsf.edu/tid/vhq75c00. [Accessed May 29, 2003]

34 Nicoli D. Weekly Bullet Report For Federal Tobacco Team. Philip Morris Companies Inc; June 19, 1998. Legacy Tobacco Document Library. Bates No. 2078294705-2078294708.FEDA/PRODUCED. http://

legacy.library.ucsf.edu/tid/whq75c00. [Accessed May 29, 2003]

35 Nicoli D. Weekly Bullet Report For Federal Tobacco Team. Philip Morris Companies Inc; February 1, 1999. Legacy Tobacco Document Library. Bates No. 2078707656/7661.FEDA/PRODUCED. http://legacy.library.ucsf.edu/ $\mathrm{tid} / \mathrm{bgz} 72 \mathrm{c00}$. [Accessed July 9, 2003]

36 Becker J. Officials fear cut tobacco funds. St Petersburg Times 11 April 2000. http://www.sptimes.com/News/041 100/State/Officials_fear_cut_to.shtml.

37 Altria Group Inc. 2002 Annual Report. New York, NY: Altria Group Inc, 7 March 2003.

38 Becker J. Bill Protects Tobacco Payments. St Petersburg Times, 6 May 2000:Sect. B6.

39 United Way of Florida. Legislative Link. United Way of Florida Tallahassee, 2000 July 28

40 Meeting of the Task Force on Tobacco Settlement Revenue Protection. In: Task Force on Tobacco Settlement Revenue Protection. Tallahassee, Florida: Accurate Stenotype Reporters, Inc., 2001.

41 Kenny M. David Adelman - Presentation to Florida Taskforce on the Tobacco Settlement. Philip Morris Companies Inc; February 28, 2001. Legacy Tobacco Document Library. Bates No. 2085760293/0294C.FEDA/PRODUCED. http://legacy.library.ucsf.edu/tid/buh41c00. [Accessed July 9, 2003]

42 Yahoo! Historical Stock Prices: Yahoo!; 2003. http://finance.yahoo.com/q/ $h p ? s=M O \& a=11 \& b=8 \& c=1999 \& d=02 \& e=8 \& f=2001 \& g=w$. [Accessed October 20 2003]

43 Task Force on Tobacco Settlement Revenue Protection. Final Report to President of the Senate and Speaker of the House of Representatives. Tallahassee, Florida, 2001 March 28.

44 Hoel J. RE: David Adelman - Presentation to Florida Taskforce on the Tobacco Settlement. Philip Morris Companies Inc; March 13, 2001. Legacy Tobacco Document Library. Bates No. 2085760293/0294C.FEDA/PRODUCED. http://legacy.library.ucsf.edu/tid/huh41c00. [Accessed July 9, 2003]

45 Hoel J. RE: "Outside In" conference call - 14 March - minutes. Philip Morris Companies Inc; March 20, 2001. Legacy Tobacco Document Library. Bates No. 2085760375/0376A.FEDA/PRODUCED. http:// legacy.library.ucsf.edu/tid/nbi41c00. [Accessed July 9, 2003] 